\title{
Periodontal Health and the Lifecourse Approach in Bioarchaeology
}

\author{
Alexandra Tuggle ${ }^{1}$ and James T. Watson ${ }^{2,3 *}$ \\ ${ }^{1}$ Department of Anthropology, The Ohio State University \\ ${ }^{2}$ Arizona State Museum, University of Arizona \\ ${ }^{3}$ School of Anthropology, University of Arizona
}

Keywords: periodontal disease, dental anthropology, lifecourse

\begin{abstract}
Healthy periodontal tissues are essential to maintaining attachment, stability, and retention of teeth. The concept of 'health' is problematic however and includes both physical and psycho-social characteristics. The challenge for bioarchaeologists is defining what physical expression begins to affect an individual's well-being. Here we apply a lifecourse approach to periodontal tissue health in a prehistoric sample $(\mathrm{N}=166)$ from the American Southwest to test the hypothesis that age and sex differences bear the greatest impact on the expression of periodontitis. Tooth loss, tooth wear, periodontal depth (CEJ-AC), and alveolar crest (AC) morphology were recorded at M1. T-tests identify that females exhibit significantly higher values across each variable. In addition, general linear modeling analyses demonstrate that values increased significantly across five age stages (15-20yo, 20-30yo, 30-40yo, 4050yo, 50+yo) with females exhibiting significantly higher values in the fourth and fifth decades of life. Results support the hypothesis that periodontal tissue loss differentially affects females across the lifecourse. Bacterial infection, chronic gingivitis, and attachment loss cause the physical symptoms of periodontal disease but may not be accompanied by pain or altered functionality. The outcome of the disease process is tooth loss, which can affect functionality and quality of life. Periodontal 'health' is therefore best interpreted in bioarchaeological samples around the point that attachment loss results in tooth loss and altered functionality.
\end{abstract}

Periodontal tissues historically receive little attention in bioarchaeological research. Periodontal 'health', however, is essential to maintaining a foundation for attachment, stability, and retention of teeth. The concept of 'health' is more than the absence of disease and is therefore problematic among both clinicians and bioarchaeologists (see Pilloud and Fancher, this issue). Mariotti and Hefti's (2015) call for redefinition of periodontal health among clinicians, using a modified wellness model, includes both physical (functional dentition and periodontal attachment stability) and psychosocial (pain and individual well-being) characteristics. The challenge for bioarchaeologists is defining what physical expression/degree within a disease process would begin to affect an individual's wellbeing. Here we therefore apply a lifecourse approach to the measurement of periodontal disease in a prehistoric sample from the American Southwest to test the hypothesis that age and sex differences bear the greatest impact on the expression of periodontitis.

Periodontal disease (PD) is the clinical characterization of destruction of the periodontium - the oral structure containing the teeth, composed of both fibrous (gingival and periodontal ligament) and mineralized (cementum and alveolar bone) tissues. Periodontal disease has a multifactorial etiology, but is primarily associated with inflammatory host response resulting from bacterial infection of periodontal tissues. Many bacterial species have been associated with the pathogenic colonization of subgingival biofilm (dental plaque) (Adriaens, De Boever, \& Loesche, 1988; Boutin et al., 2017; Socransky \& Haffajee, 2005) and the periodontal pocket provides an ideal eco-system for these organisms, containing a diverse microbiota of up to 700 prokaryote species (Boutin et al., 2017; Chen et al., 2010). Martelli and colleagues (2017) identify that the progression and severity of PD depends on the aggressiveness of the subgingival

\author{
*Correspondence to: \\ James T. Watson \\ Arizona State Museum \\ University of Arizona \\ PO Box 210026, \\ Tucson, AZ 85721 \\ watsonjt@email.arizona.edu
}


plaque biofilm and individual host immune response, which can be further affected by genetic and epigenetic contexts and environmental factors (i.e., age, sex, smoking, oral hygiene, etc.). Today, PD is also correlated with various systemic disorders, including cancer, diabetes, rheumatoid arthritis, cardiovascular diseases, and preterm birth (Jepsen et al., 2018; Martelli et al., 2017).

Studies of modern and prehistoric patterns of periodontal disease demonstrate that men generally have a higher prevalence than women (DeWitte, 2012; Shiau \& Reynolds, 2010; Wasterlain et al., 2011). DeWitte (2012) proposes that this is likely due to immuno-buffering from estrogen among women (Klein and Huber, 2010). But there is other clinical evidence to suggest that hormonal fluctuations, particularly associated with pregnancy, may have adverse effects on periodontal health (Carrillo -de-Albornoz et al., 2010; Laine, 2002; Lukacs and Largaespada, 2006; Silk et al., 2008; Wu, Chen, \& Jian, 2015). During pregnancy, production of estrogens and progesterone is increased. Estrogen levels rise to over 100 times more than pre-pregnancy levels, with progesterone levels surpassing this even more. During labor, hormone concentrations drop, reaching their pre-pregnancy levels within 23 days after delivery (Laine, 2002). After the second trimester, the placenta begins regulating hormone production to maintain the pregnancy, including maintenance of the endometrium, preparation for lactation, increase in basal metabolic rate, and regulation of the immune system. The affiliated vascularization of bodily tissues often causes the gingiva to become inflamed and retain fluid, resulting in pregnancy gingivitis and edema (Bobetsis et al., 2006; Laine, 2002).

While pregnancy does not actually cause gingivitis or periodontitis, the hormonal activity in gingival tissues can exacerbate pre-existing periodontal disease. With increased gingival inflammation and edema, the periodontium can become weakened (Laine, 2002; Silk et al., 2008). Especially in the presence of accumulated plaque and calculus, the gingiva can become detached from the tooth exposing the periodontium (Coventry et al., 2000). When bacteria infiltrate the weakened periodontium, their toxins activate a chronic inflammatory response, causing the ligaments and bone supporting the teeth to break down (Silk et al., 2008).

Current research has identified some specific pathophysiology that may contribute to PD associated with hormonal activity during pregnancy. Pregnant women experience pronounced fluctuations in the sex hormone estrogen. Estrogen acts as a ligand for estrogen receptor $B$ (ERß), which plays an important role in periodontal ligament cell function and proliferation (Jönsson et al., 2004; Liang et al., 2008; Mamalis et al., 2011; Wattanaroonwong et al., 2011). The periodontal ligament (PDL) is a connective tissue that bonds the cementum of the tooth to the alveolar bone. Collagen-producing PDL cells restore mineralized tissue and thus are essential in maintaining the structural and functional integrity of the periodontium. Human PDL cells have receptors for estrogen (ERß), which in turn has an inhibitory effect on bone-resorbing osteoclast formation in the periodontium (Wattanaroonwong et al., 2011). Fluctuations in estrogen levels during pregnancy may affect subsequent PDL cell proliferation and consequently periodontal integrity (Mamalis et al., 2011).

Changes in progesterone levels associated with pregnancy can make the subgingival microbiota significantly more anaerobic (Kornman \& Loesche, 1982; Paropkari et al., 2016). Less well explored is how salivary sex hormones affect the supragingival microbiota, which also experiences an ecological shift in association with pregnancy. Recently, Lin et al. (2018) explored the bacterial diversity and ecological shifts in the supragingival plaques of pregnant women and observed it is highly correlated with the subgingival microbiota and may equally contribute to oral dysbiosis during pregnancy. Lin et al. (2018) posited that consistent with surges in progesterone and estradiol during the third trimester, pregnancy constructs an environment conducive to some bacterial strains including members of the Neisseria and Poryphromonas genera. Progesterone may also downregulate IL-6 production by gingival fibroblasts, resulting in gingival inflammation and bacterial proliferation (Lapp et al., 1995).

Other hormones associated with significant fluctuations during pregnancy have also been explored as possible contributors to PD in women. Parathyroid hormone, a calcitropic hormone responsible for calcium metabolism, decreases in early pregnancy. This is followed by a spike in the first trimester, a decline at the middle, and another rise towards the end of a pregnancy (Hameedi, 2017). Osteocalcin, an osteoblastic hormone, mirrors parathyroid hormone fluctuations throughout pregnancy with corresponding effects on boneformation processes (Seki et al., 1991). Progesterone levels also are negatively associated with calcium levels in pregnant women (Hameedi, 2017). 
Fertility in prehistoric agricultural communities The Holocene is characterized in part by the substantial increase in human populations that occurred in a relatively small amount of time, markedly in areas that adopted agriculture (Larsen, 1995). Although the transition from foraging to farming is generally characterized by a decline in overall health (including a decline in skeletal robusticity and dental health), the archaeological record displays evidence of a "Neolithic demographic transition" (Ndt), wherein populations expanded in most agricultural communities throughout the world (Bocquet-Appel, 2002; Bocquet-Appel \& Dubouloz, 2004; Bocquet-Appel \& Naji, 2006). While population growth is apparent, sedentary settlement is also commonly associated with a reduction in mean age-at-death and high prevalence of skeletal lesions, often ascribed to nutritional deficiencies or infectious disease (Cohen \& Armelagos, 1984). A decline in health and mean age-at-death coupled with an increase in population seems paradoxical, but many contend that this trend indicates an increase in fertility rather than an increase in mortality due to poor general health (Wood, 1992). In addition, the greater prevalence of skeletal lesions evidenced in agricultural samples could alternatively reflect enhanced resilience to illness and stress (Wood, 1992).

Multiple causes for an increase in fertility among sedentary agriculturalists have been proposed. Cultivation of domestic crops such as maize in the New World would not only increase the carrying capacity of the environment, but also result in lifestyle shifts leading to increased fertility (Lukacs, 2008). More dependable, higher calorie food supplies, a reduction in workload, and more readily available weaning foods would both increase the energy available to mothers and decrease the necessary weaning time. Fecundity (the biological potential for childbearing) can be sensitive to energetic stress, and even moderate energetic stress appears to suppress ovarian hormone levels (Ellison et al., 2012). With decreased mobility associated with an agricultural lifestyle and a carbohydrate-based, calorie-dense diet, women would likely be under less energetic stress and thus more fecund.

A shorter weaning period may also influence fertility by a reduction in interbirth intervals. Lactation suppresses ovulation and often has a contraceptive effect due to the results of lactational amenorrhea (Kennedy \& Visness, 1992; WHO, 1999). However, variation in the contraceptive effect seems to be related to maternal energetic state. Re- search shows that maternal physiology acts to lower the chance of another conception when energetic investment in the current child is still high. Lactation is energetically expensive, and if the weaning age is decreased due to supplementation of weaning foods, the mother may return to a fecund state more quickly (Ellison, Bogin, \& O'Rourke, 2012). Ethnographic comparisons with modern foraging societies show that they generally exhibit longer interbirth intervals (generally 3-4 years) and decreased fertility due to longer breastfeeding periods, higher mobility/activity level, and seasonal weight fluctuations with resource availability (Eshed et al., 2004; Hitchcock, 1982; Howell, 1979). In addition, higher rates of infant mortality (as experienced by early agricultural populations) can increase fertility by returning a mother to a fecund state after the loss of a breastfeeding child (Ellison, Bogin, \& O'Rourke, 2012).

Given the complex interplay between reproductive hormones and the reproductive burden associated with burgeoning population growth among prehistoric agricultural groups, the cumulative effects of high fertility rates would differential affect women in these prehistoric communities. We therefore suggest that age and sex differences have the greatest impact on the expression of periodontal disease, which may be a function of high fertility. Here we apply a lifecourse approach to the measurement of periodontal disease in a prehistoric sample from the American Southwest to test this hypothesis.

\section{Materials and Methods}

The samples analyzed in this study were recovered from a series of archaeological sites associated with the Mogollon archaeological culture (Fig. 1). The Mogollon archaeological culture is associated with Ancestral Puebloan occupation of the rugged intermontane region of east-central Arizona and westcentral New Mexico (Reid \& Whittlesey, 1997). The Mogollon area is physiographically diverse with low valleys containing desert and grassland ecosystems and high elevations ( 6,000 feet) characterized by large, Ponderosa pine forests and juniper/ piñon woodlands (Reid, 2006; Woodbury, 1961). Although agriculture, particularly reliant on maize, was the foundation of their subsistence economy, a variety of local wild resources continued to provide an important role in the diet (Reid \& Whittlesey, 1997; Woodbury, 1961).

The Pueblo Period of Mogollon development in Arizona began around A.D. 1100 with the transition from pit houses to masonry construction and 


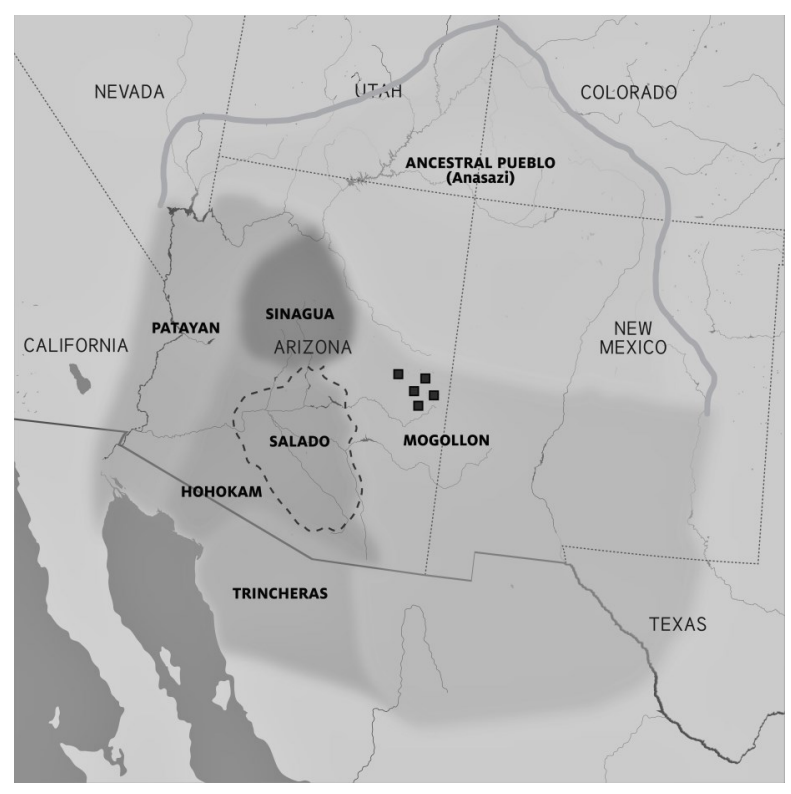

Figure 1. Map of Southwest US/Northwest Mexico with the Mogollon archaeological culture area defined by dashed line, and location of sites plotted (marked by squares). Map reproduced with permission from Arizona State Museum.

lasted until about A.D. 1400 when the pueblos were abandoned and populations became effectively archaeologically invisible (Reid \& Whittlesey, 1997). This period is characterized by rapid population growth and nucleation into fewer, larger villages. Nucleation resulted in denser population concentrations within groups but larger distances between groups (Tuggle, 1970). As population densities increased, pueblo residents became more dependent on cultivated crops and relied less on foraging wild resources. Sometime around A.D. 1400 , as most communities neared the maximum population density that could be supported by available agricultural technologies and exhausted their wild resources, Mogollon villages were largely abandoned. Environmental pressure was aggravated by several periods of drought, resulting in migration out of the region (Reid \& Whittlesey, 1997; Tuggle, 1970). There is also evidence of significant economic and social tensions (Reid and Whittlesey, 1997).

Skeletal remains from five Mogollon sites were analyzed for evidence of periodontal disease. The sites include Point of Pines, Turkey Creek, Kinishba, King Ruin, and AZ:W:10:52(ASM), which represent a series of large, multi-room pueblos that emerged in the Mogollon region with occupations that ranged between A.D. 1225 to 1450 (East, 2008; Haury, 1989; Lowell, 1991; Welch,
2016). Together these samples represent a 225 -year sequence of population growth, until social collapse, reorganization, migration, and partial abandonment of the Mogollon area. Based in successful agricultural adaptations, it is likely that a combination of environmental and social stressors led to eventual collapse. The demographic profile, including generally a higher infant mortality fits the curve proposed by Bocquet-Appel (2002) as representing high fertility populations and therefore make ideal samples to test the relationship between periodontal disease and sex across the lifecourse.

The Mogollon samples are part of the Bioarchaeology Collection at the Arizona State Museum (ASM), University of Arizona in Tucson, Arizona. Sex and age data were obtained from the Arizona State Museum Human Remains Database, estimated previously by ASM curators using macroscopic aspects of the pelvis and/or cranium for sex (Buikstra and Ubelaker, 1994), and macroscopic changes in the pubic symphysis (Buikstra \& Ubelaker, 1994) and relative rates of dental attrition (Brothwell, 1989) for age. Individuals of indeterminate sex or age were excluded from the analysis.

Table 1 displays the distribution of samples by site, age, and sex. The 166 individuals were separated into five decadal age sets representing the sequence from late juvenile to senescence. We focused our analysis on the first permanent mandibular molar (M1) because periodontal disease differentially affects posterior teeth (Kerr, 1989) and the first molar is in occlusion the longest among the posterior teeth, thereby having the greatest potential for the expression of PD over the lifecourse.

The remains were analyzed at the ASM by James Watson and Theodora Burbank and included 1) an inventory of teeth including antemortem loss, 2) recording occlusal surface wear (Wear) according

Table 1. Archaeological samples used in analysis

\begin{tabular}{lcccccc}
\hline Site & Sex & $15-20$ & $20-30$ & $30-40$ & $40-50$ & $50+$ \\
\hline Point of & $\mathrm{M}$ & 1 & 9 & 9 & 3 & 1 \\
Pines & $\mathrm{F}$ & 5 & 12 & 10 & 3 & 0 \\
\hline Turkey & $\mathrm{M}$ & 2 & 4 & 10 & 13 & 4 \\
Creek & $\mathrm{F}$ & 2 & 5 & 9 & 11 & 6 \\
\hline \multirow{2}{*}{ Kinishba } & $\mathrm{M}$ & 3 & 5 & 7 & 0 & 1 \\
& $\mathrm{~F}$ & 7 & 4 & 4 & 2 & 0 \\
\hline King & $\mathrm{M}$ & 0 & 0 & 0 & 1 & 0 \\
Ruin & $\mathrm{F}$ & 0 & 1 & 1 & 1 & 0 \\
\hline AZ:W:10: & $\mathrm{M}$ & 0 & 3 & 3 & 1 & 0 \\
52 & $\mathrm{F}$ & 0 & 2 & 0 & 1 & 0 \\
\hline
\end{tabular}

2019 | Volume 32 | Issue 02 
to Scott (1979), 3) measuring distance of the alveolar crest (AC) from the cemento-enamel junction (CEJ) on the buccal surface of M1 (CEJ-AC) with a periodontal probe (Hu-Friedy UNC-15 color-coded periodontal probe), and 4) alveolar crest (AC) morphology according to Kerr (1988).

Independent samples $t$-tests are used to compare mean values for Wear, CEJ-AC, and AC and a Mann-Whitney U test to compare frequency of tooth loss between sexes. In addition, general linear modeling analysis (Gill, 2001) - with age as the covariate and sex as the grouping factorcompares mean values between sexes across age groups. All statistical procedures were performed using IBM SPSS Statistics for Windows, v25.0 (SPSS Inc., Chicago, IL., USA).

\section{Results}

Preliminary comparisons by sex identify significant differences in mean values, with females exhibiting higher rates of wear, deeper CEJ-AC depths, and more compromised alveolar crest morphology (Table 2). In addition, the Mann-Whitney $\mathrm{U}$ test indicates that tooth loss was greater for females (mean rank: 76.01) than males (mean rank: 91.55), $U=6537.0, p=.006$.

Comparisons across age groups demonstrate the general age-related progression of periodontal attachment loss that is typical of the general trend in clinical studies (Billings et al., 2018; Eke et al., 2018). The results of the general linear modeling analysis show similar significant differences in tooth wear, alveolar crest depth, and alveolar crest morphology between males and females across age grades (Table 3). Figures 2-4 plot the means and $95 \%$ confidence intervals of each variable across age groups demonstrating similar patterns over the life course. Mean values are similar between males and females in the youngest age cohorts but begin to separate in the fourth and fifth decades of life, only to return to closer values in the final decade (s).

In addition to measurable attachment loss of the alveolar crest, tooth loss at M1 was significant. Tooth loss is again more pronounced among females compared to males in the middle decades of life; 30-40yo and 40-50 (Fig. 5).

\section{Discussion}

Our results support the hypothesis that periodontal disease can be measured across the lifecourse (using the proxy measurements observed here) and demonstrate that females suffered disproportionately from tooth and periodontal tissue loss. Periodontal attachment loss differed over the lifecourse; however, with both sexes experiencing similar (non-significant) periodontal tissue depths and morphology in the early age grades and experiencing significant increases after roughly age 30 . Males appear to display a steady, age-related decline in periodontal tissue quality that only again approaches higher female levels in the oldest age

Table 2. Results of independent samples t-tests for variables by sex

\begin{tabular}{lccccccc}
\hline \multirow{2}{*}{ Variable } & Sex & $\mathrm{N}$ & Mean & s.d. & $t$ & $d f$ & Sig. \\
\hline \multirow{2}{*}{ Wear } & $\mathrm{M}$ & 80 & 3.59 & 1.17 & -4.682 & \multirow{2}{*}{164} & $<0.001$ \\
\hline \multirow{2}{*}{ CEJ-AC } & $\mathrm{F}$ & 86 & 4.58 & 1.53 & & \\
\hline \multirow{2}{*}{ AC } & $\mathrm{M}$ & 80 & 2.11 & 1.21 & -3.695 & \multirow{2}{*}{164} & $<0.001$ \\
& $\mathrm{~F}$ & 86 & 2.81 & 1.23 & & & \\
& $\mathrm{~F}$ & 80 & 2.09 & 0.93 & -5.656 & \multirow{2}{*}{164} & $<0.001$ \\
\hline
\end{tabular}

Table 3. Results for general linear modeling by sex and age groups

\begin{tabular}{cccccccccc}
\hline Variable & Sex & $15-20$ & $20-30$ & $30-40$ & $40-50$ & $50+$ & $F$ & $d f$ & Sig. \\
\hline \multirow{2}{*}{ Wear } & $\mathrm{M}$ & 3.0 & 3.0 & 4.0 & 4.0 & 4.0 & \multirow{2}{*}{31.030} & \multirow{2}{*}{2} & $<0.001$ \\
& $\mathrm{~F}$ & 3.0 & 4.0 & 5.0 & 5.0 & 6.0 & & & \\
\hline \multirow{2}{*}{ CEJ-AC } & $\mathrm{M}$ & 1.0 & 2.0 & 2.0 & 2.0 & 3.0 & \multirow{2}{*}{20.659} & \multirow{2}{*}{2} & \multirow{2}{*}{$<0.001$} \\
& $\mathrm{~F}$ & 2.0 & 2.0 & 3.0 & 3.0 & 4.0 & & & \\
\hline \multirow{2}{*}{$\mathrm{AC}$} & $\mathrm{M}$ & 2.0 & 2.0 & 2.0 & 2.0 & 3.0 & \multirow{2}{*}{30.433} & \multirow{2}{*}{2} & $<0.001$ \\
& $\mathrm{~F}$ & 2.0 & 3.0 & 3.0 & 3.0 & 4.0 & & & \\
\hline
\end{tabular}




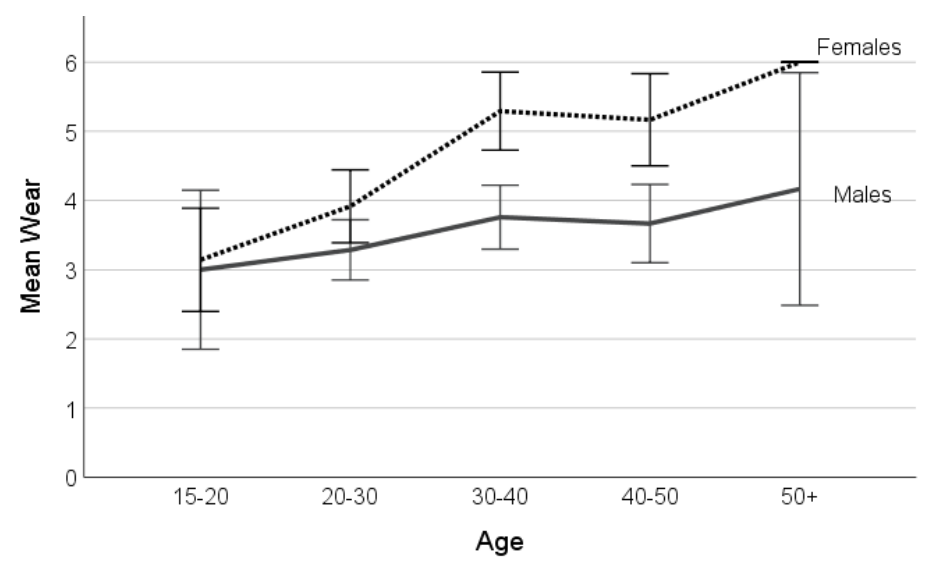

Figure 2. Mean wear score (from Scott, 1979) at M1 plotted by age groups for males and females. Error bars represent $95 \%$ confidence intervals.

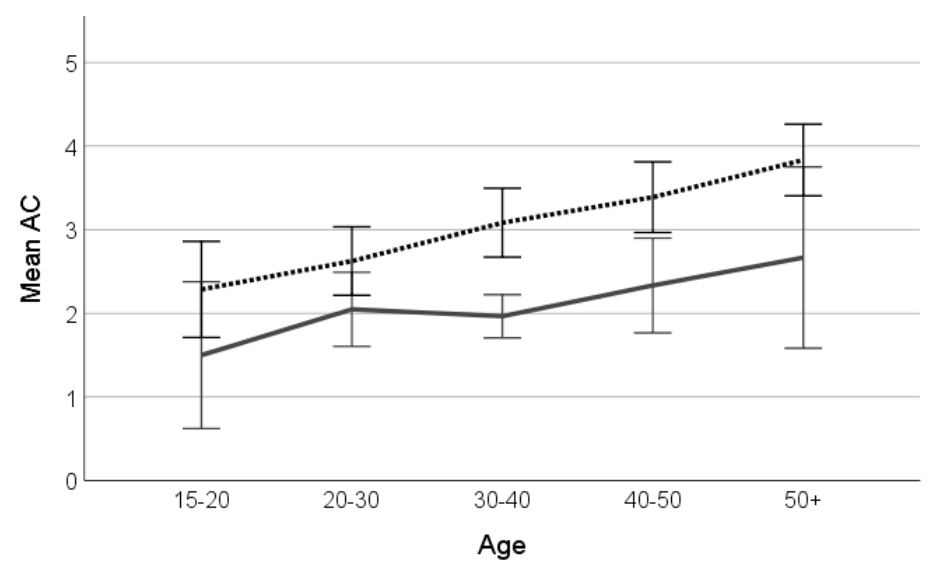

Figure 4. Mean alveolar crest morphology score (from Kerr, 1988) at M1 plotted by age groups for males and females. Error bars represent $95 \%$ confidence intervals.

grade; and this is more related to greater variability in expression among males rather than a final spike in tooth and tissue loss. Significant differences between sexes from 30 to 50 years suggests an underlying biological phenomenon negatively affecting women's oral health.

We propose that hormonal fluctuations associated with reproduction and higher parity in prehistoric Mogollon communities are the cause of disparities in periodontal retreat and tooth loss between sexes. Tooth loss specifically can also result from dental caries, pulp exposure from heavy wear, and trauma; but the co-occurring trends observed in the data suggest inter-related processes contributing to tooth loss. It is likely that trends in caries frequency in the sample would mirror those

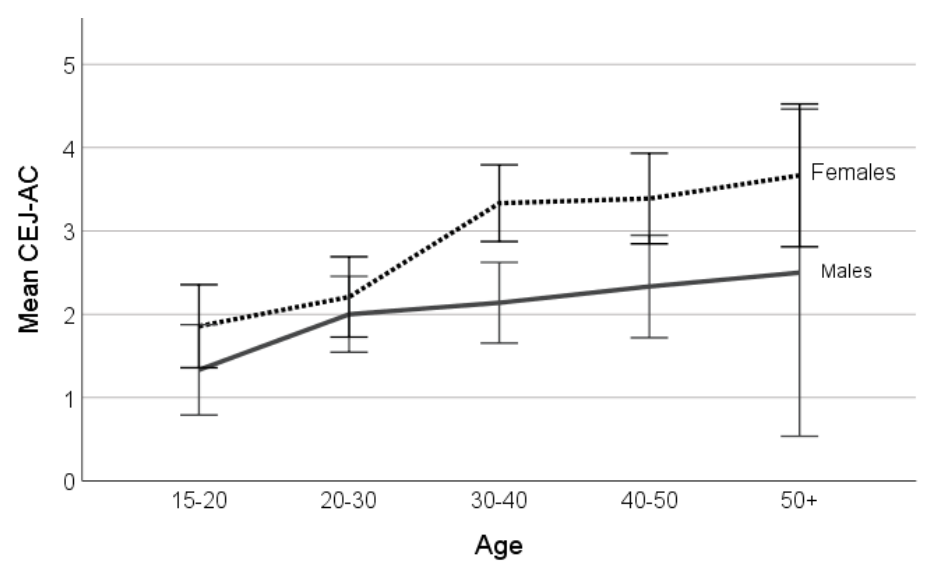

Figure 3. Mean distance $(\mathrm{mm})$ from the cemento-enamel junction on the buccal surface of M1 to the alveolar crest plotted by age groups for males and females. Error bars represent $95 \%$ confidence intervals.

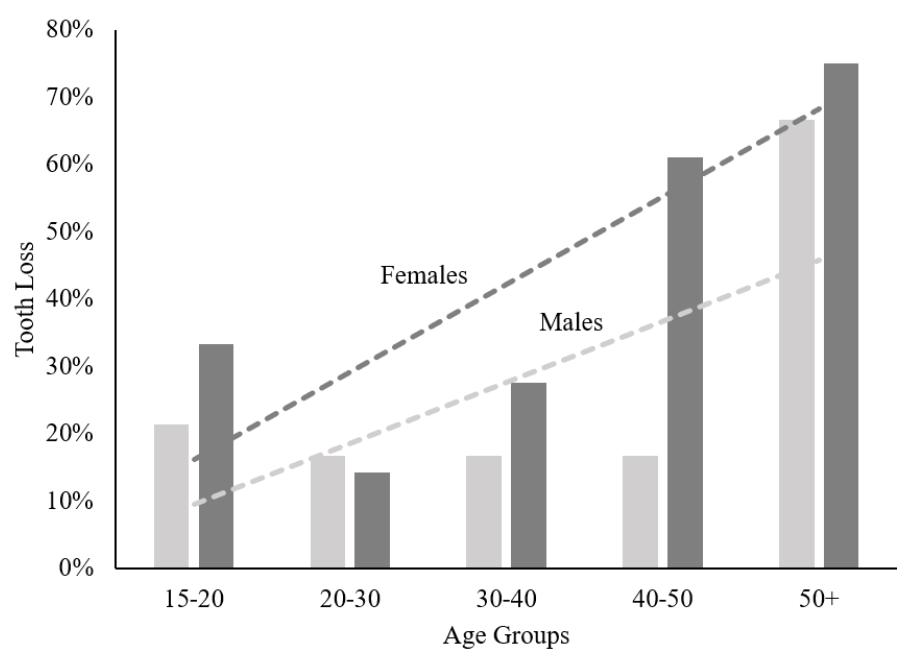

Figure 5. Frequency (\%) of tooth loss at M1 plotted by age groups for males and females.

observed in periodontal tissues but is beyond the scope of the current study. Tooth wear also appears to have played a role in destabilizing periodontal tissues through continuous eruption in response to heavy tooth wear. Yet, tooth wear also increases significantly in the interval from 30 to 50 years where female periodontal health incrementally declines compared to males and is perhaps exacerbated by tooth loss, loss of contact, and malocclusion.

Clinical and epidemiological research shows that the hormonal fluctuations associated with reproductive physiology play a substantial role in maintaining healthy periodontal tissues (Laine, 2002; Wu et al., 2015). Evidence from ethnographic accounts and the archaeological record suggests a 
general pattern of increased fertility with the adoption of agriculture in most areas (Bocquet-Appel \& Naji, 2006; Eshed et al., 2004). Sedentism is associated with lifestyle changes that could critically impact fertility, including increased availability of energy-dense foods, decreased mobility, and shorter interbirth intervals (Ellison et al., 2012; Lukacs, 2008). A cariogenic diet reliant on maize undoubtedly played a crucial role in the overall decline in oral health observed in prehistoric agricultural populations of the Southwest US/Northwest Mexico. Dietary composition and high fertility likely led to an environment in which women experienced exacerbated oral pathology (Watson et al., 2009). This study contributes some insights into the oral health of women in prehistoric agricultural communities in Arizona.

The impact of pregnancy and reproduction has been largely avoided in archaeological literature, in part due to the difficulty associated with its study. While this study barely scratches the surface of the problem, it highlights a need to engage with life history theory and acknowledge the influences of reproductive life history on women's health in archaeological research. Although current medical and dental therapy place emphasis on improving the well-being of pregnant women and their unborn children (Jared \& Boggess, 2008; Russell \& Mayberry, 2008; Sanz \& Kornman, 2013), data show that increased parturition is still related to increased tooth loss in a woman's lifespan (Christensen et al., 1998; Russell et al., 2008). This trend of increased tooth loss extends across cultural and socio-economic boundaries. It probably is related to the ongoing problem of untreated dental disease, which includes maternal periodontitis (Jeffcoat et al., 2001; Offenbacher et al., 1996).

Our results specifically demonstrate that cumulative effects among reproductive-age and post reproductive-age females caused disproportionate tooth and periodontal tissue loss. Hormone fluctuations associated with reproductive physiology play a substantial role in maintaining healthy periodontal tissues (Wu, Chen, \& Jiang, 2015). Bacterial infection, chronic gingivitis and attachment loss cause the physical signs and symptoms of periodontal disease. However, this inflammatory destruction of the periodontium often is not accompanied by pain or altered function until advanced degrees of destruction. The penultimate outcome of the disease process is tooth loss, which can affect functionality and quality of life.

Periodontal 'health' is therefore best interpreted/conceptualized in bioarchaeological samples around the point that attachment loss destabilizes the tooth and results in loss and altered functionality. Although still stemming from a 'diseasefocused' approach, we consider how functional occlusion plays a significant role in health. In addition, the pain and process involved in tooth loss and removal will significantly impact quality of life, followed by altered functionality and differential wear. This allows bioarchaeologists to relate past people's physical conditions to modern clinical and epidemiological understandings of health and pathology.

\section{Acknowledgements}

We would like to express our gratitude to Theo Burbank for assisting with data collection on several of the skeletal collections, to Marin Pilloud and J. P. Fancher for their invitation to contribute to the 2018 AAPA poster symposium dedicated to "Reevaluating the meaning of 'oral health' in bioarchaeology", to Marin Pilloud for the invitation to contribute to this special issue of Dental Anthropolo$g y$, and again to J. P. Fancher for extensive comments that led to a much improved manuscript.

\section{REFERENCES}

Adriaens, P.A., De Boever, J.A., Loesche, W.J. (1988). Bacterial invasion in root cementum and radicular dentin of periodontally diseased teeth in humans. A reservoir of periodontopathic bacteria. Journal of Periodontology, 59, 222 -230 .

Billings, M., Holtfreter, B., Papapanou, P.N., Mitnik, G.L., Kocher, T., and Dye, B.A. (2018). Age -dependent distribution of periodontitis in two countries: Findings from NHANES 2009 to 2014 and SHIP-TREND 2008 to 2012. Journal of Periodontology, 89, S1, S140-S158.

Bobetsis, Y.A., Barros, S.P., and Offenbacher, S. (2006). Exploring the relationship between periodontal disease and pregnancy complications. Journal of the American Dental Association, 137 (Suppl), 7S-13S.

Boquet-Appel, J-P. (2002). The paleoanthropological traces of the Neolithic demographic transition. Current Anthropology, 43, 638-650.

Boquet-Appel, J-P. and Dubouloz, J. (2004). Expected paleoanthropological and archaeological signal from a Neolithic demographic transition on a worldwide scale. Documenta Praehistorica, 31, 25-33.

Boquet-Appel, J-P. and Naji, S. (2006). Testing the hypothesis of a worldwide Neolithic demographic transition. Current Anthropology, 47, 
341-365.

Boutin, S., Hagenfeld, D., Zimmermann, H., El Sayed, N., Höpker, T., Greiser, H.K., Becher, H., Kim, T-S. ,\& Dalpke, A.H. (2017). Clustering of Subgingival Microbiota Reveals Microbial Disease Ecotypes Associated with Clinical Stages of Periodontitis in a Cross-Sectional Study. Frontiers in Microbiology, 8, 340-353.

Brothwell, D. (Ed.). (1989). The relationship of tooth wear to aging. In Işcan MY, Age Markers in the Human Skeleton (pp. 303-318). Springfield: Charles C. Thomas Publisher.

Buikstra, J.E. \& Ubelaker, D.H. (1994). Standards for data collection from human skeletal remains. Arkansas Archeological Survey Research Series, 44.

Carrillo-de-Albornoz, A.E., Figuero, D., Herrera, P., \& Bascones-Martínez, A. (2010). Gingival changes during pregnancy: II. Influence of hormonal variations on the subgingival biofilm. Journal of Clinical Periodontology, 37( 3), 230-40.

Carrillo-de-Albornoz, A.E., Figuero, D., Herrera, P., \& Bascones-Martínez, A. (2012). Gingival changes during pregnancy: III. Impact of clinical, microbiological, immunological, and sociodemographic factors on gingival inflammation. Journal of Clinical Periodontology, 39, 272-83.

Chen, T., Yu, W-H., Izard, J., Baranova, O.V., Lakshmanan, A., \& Dewhirst, F.E. (2010). The human oral microbiome database: a web accessible resource for investigating oral microbe taxonomic and genomic information. Database (Oxford); 2010 baq013.

Christensen, K., Gaist, D., Jeune, B., \& Vaupel, J.W. (1998). A tooth per child? The Lancet, 352 (9123), 204.

Christian, L.M. (2015). Stress and immune function during pregnancy: an emerging focus in mind -body medicine. Current Directions in Psychological Science, 24(1), 3-9.

Cohen, M.N. \& Armelagos, G.J. (Eds.). (1984). Paleopathology at the origins of agriculture. New York, NY: Academic Press.

Cohen, M.N. \& Crane-Kramer, G.M.M. (Eds.). (2007). Ancient health: Skeletal indicators of Aaricultural and economic intensification. Gainesville, FL: University Press of Florida.

Coventry, J., Griffiths, G., Scully, C., \& Tonetti, M. (2000). ABC of oral health: periodontal disease. British Medical Journal, 321(7252), 36-39.

East, A. (2008). Reproduction and prenatal care in Arizona prehistory: An examination of patterns of health in perinates and children at Grasshopper, Point of Pines, and Turkey Creek Pueblos. Ph.D. dissertation, University of New Mexico. Ann Arbor, MI: ProQuest LLC.

Eke, P.I., Thornton-Evans, G.O., Wei, L., Borgnakke, W.S., Dye, B.A., \& Genco, R.J. (2018). Periodontitis in US adults: National health and nutrition examination survey 20092014. The Journal of the American Dental Association, 149(7), 576-588.e576.

Ellison, P.T., Bogin, B., \& O'Rourke, M.T. (2012). Demography part 2: Population growth and fertility regulation. In S. Stinson, B. Bogin, and D. O'Rourke (Eds.), Human Biology: An Evolutionary and Biocultural Perspective (pp. 757803). Hoboken, NJ: Wiley Blackwell.

Eshed, V., Gopher, A., Gage, T.B., \& Hershkovitz, I. (2004). Has the transition to agriculture reshaped the demographic structure of prehistoric populations? New evidence from the Levant. American Journal of Physical Anthropology, 124, 315-329.

Fields, M., Herschaft, E.E., Martin, D.L., \& Watson, J.T. (2009). Sex and the agricultural transition: Dental health of early farming females. Journal of Dentistry and Oral Hygiene, 1(4), 42-51.

Gill, J. (2001). General linear models: A unified approach. Thousand Oaks, CA: Sage Publications.

Hameedi, B.H. (2017). Estimation of parathyroid hormone, progesterone and prolactin, with some electrolyte in sera of first trimester Iraqi pregnant women. International Journal of Science and Nature, 8(3), 710-713.

Haury, E.W. (1989). Point of Pines, Arizona: A history of the University of Arizona archaeological field school. In Anthropological Papers of the University of Arizona No. 50. Tucson, AZ: University of Arizona Press.

Hillson, S. (2002). Dental anthropology. Cambridge: Cambridge University Press.

Hitchcock, R.K. (1982). Patterns of sedentism among the Besarwa of eastern Botswana. In E. Leacock and R.B. Lee (Eds.), Politics and History in Band Societies, (pp. 223-268). Cambridge: Cambridge University Press.

Howell, N. (1979). Demography of the Dobe !Kung!. New York, NY: Academic Press.

Jared, H., \& Boggess, K. (2008). Periodontal diseases and adverse pregnancy outcomes: a review of the evidence and implications for clinical practice. Journal of Dental Hygiene, 82(3), 2-20.

Jeffcoat, M.K., Geurs, N.C., Reddy, M.S., Cliver, S.P., Goldenberg, R L., \& Hauth, J.C. (2001). Periodontal infection and preterm birth: Results of a prospective study. The Journal of the 
American Dental Association, 132(7), 875-880.

Jepsen, S., Caton, J.G., Albandar, J.M., Bissada, N F., Bouchard, P., Cortellini, P., \& Yamazaki, K. (2018). Periodontal manifestations of systemic diseases and developmental and acquired conditions: Consensus report of workgroup 3 of the 2017 world workshop on the classification of periodontal and peri-implant diseases and conditions. Journal of Periodontology, 89 (S1), S237-S248.

Jönsson, D., Andersson, G., Ekblad, E., Liang, M., Bratthall, G., \& Nilsson, B.-O. (2004). Immunocytochemical demonstration of estrogen receptor $\beta$ in human periodontal ligament cells. Archives of Oral Biology, 49, 85-88.

Kennedy, K.I. \& Visness, C.M. (1992). Contraceptive efficacy of lactational amenorrhoea. The Lancet, 339(8787), 227-230.

Kerr, N.W. (1988). A method of assessing periodontal status in archaeologically derived skeletal material. Journal of Paleopathology, 2(2) 67-78.

Kerr, N.W. (1989). The periodontal status of a Scottish Mediaeval Cohort. Journal of Paleopatholo$g y, 2,119-128$.

Klein, S.L., \& Huber, S. (2010). Sex differences in susceptibility to viral infection. In S.L. Klein, and C. Roberts, (Eds.), Sex Hormones and Immunity to Infection (pp 93-122). Heidelberg: Springer.

Kornman, K.S. \& Loesche, W.J. (1982). Effects of estradiol and progesterone on Bacterioides melaninogenicus and Bacterioides gingivalis. Infection and immunity, 35(1), 256-263.

Laine, M.A. (2002). Effect of pregnancy on periodontal and dental health. Acta Odontologica Scandinavica, 60, 257-264.

Lapp, C.A., Thomas, M.E., \& Lewis, J.B. (1995). Modulation by progesterone of interleukin- 6 production by gingival fibroblasts. Journal of Periodontology, 66, 279-284.

Larsen, C.S. (1995). Biological changes in human populations with agriculture. Annual Review of Anthropology, 24, 185-213.

Larsen, C.S. (1998). Gender, health, and activity in foragers in the American Southeast: implications for social organization in the Georgia Bight. In A.L. Grauer and P. Stuart-Macadam (Eds.), Sex and Gender in Paleopathological Perspective (pp. 165-187). Cambridge: Cambridge University Press.

Larsen, C.S. (2002). Bioarchaeology: The lives and lifestyles of past people. Journal of Archaeological Research, 10, 2, 119-166.

Larsen, C. S. (2015). Bioarchaeology: Interpreting be- havior from the human skeleton (second edition). Cambridge: Cambridge University Press.

Liang, L., Yu, J.-F., Wang, Y., Wang, G., \&Ding, Y. (2008). Effect of estrogen receptor beta on the osteoblastic differentiation function of human periodontal ligament cells. Archives of Oral Biology, 53, 553-557.

Lin, W., Jiang, W., Hu, X., Gao, L., Ai, D., Pan, H., \& Huang, Z. (2018). Ecological shifts of supragingival microbiota in association with pregnancy. Frontiers in Cellular and Infection Microbiology, 8, 24.

Lowell, J.C. (1991). Prehistoric households at Turkey Creek Pueblo, Arizona. In Anthropological Papers of the University of Arizona No. 54. Tucson, AZ: University of Arizona Press.

Lukacs, J.R. (2008). Fertility and agriculture accentuate sex differences in dental caries rates. Current Anthropology, 49, 901-914.

Lukacs, J.R. \& Largaespada, L.L. (2006). Explaining sex differences in dental caries prevalence: saliva, hormones and "life-history" etiologies. American Journal of Human Biology, 18, 540-555.

Mamalis, A., Markopoulou, C., Lagou, A., \& Vrotsos, I. (2011). Oestrogen regulates proliferation osteoblastic differentiation, collagen synthesis and periostin gene expression in human periodontal ligament cells through oestrogen receptor beta. Archives of Oral Biology, 56, 446-455.

Martelli, M.L., Brandi, M.L., Martelli, M., Nobili, P., Medico, E., \&Martelli, F. (2017). Periodontal disease and women's health. Current Medical Research and Opinion, 33(6), 1005-1015.

Nelson, G.C. (2016). A host of other dental diseases and disorders. In J.D. Irish and G.R. Scott (Eds.), A Companion to Dental Anthropology (pp. 465-483). West Sussex, UK: Wiley Blackwell.

Offenbacher, S., Katz, V., Fertik, G., Collins, J., Boyd, D., Maynor, G., \& Beck, J. (1996). Periodontal infection as a possible risk factor for preterm low birth weight. Journal of Periodontology, 67(10s), 1103-1113.

Paropkari, A.D., Leblebicioglu, B., Christian, L.M., \& Kumar, P.S. (2016). Smoking, pregnancy, and the subgingival microbiome. Scientific Reports, 6, 30388.

Pearce-Duvet, J.M.C. (2006). The origin of human pathogens: Evaluating the role of agriculture and domestic animals in the evolution of human disease. Biology Review, 81, 369-382.

Reid, J.J. (2006). A Grasshopper perspective on the Mogollon of the Arizona mountains. In L.S. Cordell and G.J. Gumerman (Eds.), Dynamics of Southwest Prehistory. Tuscaloosa, AL: Universi- 
ty of Alabama Press.

Reid, J.J. \& Whittlesey, S. (1997). The Archaeology of Ancient Arizona. Tucson, AZ: University of Arizona Press.

Russell, S.L., Ickovics, J.R., \& Yaffee, R.A. (2008). Exploring potential pathways between parity and tooth loss among American women. American Journal of Public Health, 98(7), 1263-1270.

Russell, S.L., \& Mayberry, L. (2008). Pregnancy and oral health: A review and recommendations to reduce gaps in practice and research. MCN Am J Matern Child Nurs, 33(1), 32-37.

Sanz, M., \&Kornman, K. (2013). Periodontitis and adverse pregnancy outcomes: consensus report of the Joint EFP/AAP Workshop on Periodontitis and Systemic Diseases. Journal of Periodontology, 84(4-s), S164-S169.

Scott, E. C. (1979). Dental wear scoring technique. American Journal of Physical Anthropology, 51, 213-218.

Seki, K., Makimura, N., Mitsui, C., Hirata, J., \& Nagata, I. (1991). Calcium-regulating hormones and osteocalcin levels during pregnancy: A longitudinal study. American Journal of Obstetrics and Gynecology, 164(5), 1248-1252.

Shiau, H.J., \& Reynolds, M.A. (2010). Sex differences in destructive periodontal disease: A systematic review. Journal of Periodontology, 81, 1379-1389.

Silk, H., Douglass, A.B., Douglass, J.M., \& Silk, L. (2008). Oral health during pregnancy. American Family Physician, 77(8), 1139-1144.

Socransky, S.S. \& Haffajee, A.D. (2005). Periodontal microbial ecology. Periodontology 2000, 38(1), 135-187.

Tuggle, H.D. (1970). Prehistoric Community Relationships in East Central Arizona. Ph.D Dissertation, University of Arizona. Ann Arbor, MI: University Microfilms.

Wasterlain, S. N., Cunha, E. \& Hillson, S. (2011). Periodontal disease in a Portuguese identified skeletal sample from the late nineteenth and early twentieth centuries. American Journal of Physical Anthropology, 145, 30-42.

Watson, J.T., Fields, M., \& Martin, D.L. (2009). Introduction of agriculture and its effects on women's oral health. American Journal of Human Biology, 22, 92-102.

Wattanaroonwong, N., Schoenmaker, T., de Vries, T.J., \& Everts, V. (2011). Oestrogen inhibits osteoclast formation induced by periodontal ligament fibroblasts. Archives of Oral Biology, 56, 212-219.

Welch, J.R. (2016). The site that nobody really knows: Kinishba revisited. Archaeology Southwest, 30(1).

Whittlesey, S.M., \& Reid, J.J. (2001). Mortuary ritual and organizational inferences at Grasshopper Pueblo, Arizona. In D.R Mitchell \& J.L. Brunson-Hadley (Eds.), Ancient Burial Practices in the American Southwest: Archaeology, Physical Anthropology, and Native American Perspectives (pp. 68-96). Albuquerque: University of New Mexico Press.

WHO. (1999). The World Health Organization multinational study of breast-feeding and lactational amenorrhea. III. Pregnancy during breast-feeding. Fertility and Sterility, 72(3), 431440).

Wood, J.W., Milner, G.R., Harpending, H.C., \& Weiss, K.M. (1992). The osteological paradox: Problems of inferring prehistoric health from skeletal samples. Current Anthropology, 33(4), 343-358.

Woodbury, R.B. (1961). Prehistoric Agriculture at Point of Pines, Arizona. Salt Lake City, UT: University of Utah Press.

Wu, M., Chen, S-W., \& Jiang, S-Y. (2015). Relationship between gingival inflammation and pregnancy. Mediators of Inflammation, vol. 2015, Article ID 623427, 11 pages. 